\title{
Letrōnica
}

\section{A literatura sob o signo de Caim: os gênios malditos}

The literature under Cain's sign: the cursed geniuses

Gustavo Ramos de Souza ${ }^{1}$

1 Mestre em Estudos Literários, pela Universidade Estadual de Londrina. Atualmente, é doutorando em Estudos Literários, pela mesma instituição, com pesquisa sobre râneo.

avulsoaoavesso@gmail.com
RESUMO: 0 presente ensaio tem por objetivo delinear um percurso mítico e histórico da poesia enquanto maldição, buscando relacionar a parábola de Abel e Caim ao ethos da literatura moderna. Para tanto, em um primeiro momento, a ideia é verificar de que modo os poetas são descendentes de Caim, o fratricida proscrito. Em um segundo momento, buscamos identificar uma relação entre o gênio criador e a melancolia/doença. Por fim analisando os casos de Balzac e Rimbaud, é possível notar alguns motivos da poesia maldita: orgulho, revolta, satanismo e melancolia. Ressalta-se que ao discurso literário e ao teórico será dado o mesmo valor, ou seja, a poesia assume o estatuto de teoria, e vice-versa.

PalaVras-CHAVE: Poetas malditos; Melancolia; Gênio; Romantismo; Modernidade.

ABSTRACT: This paper aims to delineate a mythical and historical path of the poetry as curse, seeking to relate the parable of Abel and Cain with the ethos of modern literature. Therefore, at first, the idea is to verify how the poets are descendants of Cain, the outcast fratricide. In a second moment, we seek to identify a relation between creative genius and melancholy/disease. Finally, analyzing the cases of Balzac and Rimbaud, it's possible to note some motifs of the accursed poetry: pride, rebellion, Satanism and melancholy. We emphasize that, to the literary and theoretical discourse, it will be given the same value, i.e., poetry takes the status of theory, and vice versa.

KEYwoRDS: Cursed poets; Melancholy; Genius; Romanticism; Modernity. 


\section{A maldição de Caim}

"Não deis o que é santo a cachorros nem atireis vossas pérolas a porcos, para não acontecer que estes as calquem com suas patas e aqueles, voltando-se, vos dilacerem." (Mateus: 7; 6)

A

dão, o primeiro homem, foi também o primeiro poeta. A sua poesia,

despida de qualquer pretensão metafísica - haja vista que lhe foi vedado comer os frutos da árvore do conhecimento do bem e do mal -, exprime perfeitamente o significado da palavra grega poiesis. A tradução de poiesis significa criação, produção, confecção. Foi só depois que o seu significado foi transferido para a poética. Poiesis é criação, não como o Verbum Dei - a palavra criadora, mas porque cria a linguagem, cria a própria palavra. Por outro lado, a palavra de Deus, do Fiat Lux, cria a luz, cria o mundo. A palavra divina, antes da Criação, existia apenas em sua natureza conceitual, ou seja: a priori da linguagem. ${ }^{1}$ De fato, não se pode falar, nesse caso, nem mesmo de metafísica, já que não havia um mundo físico para lhe contrapor. Existia apenas linguagem, espírito.

Eis a passagem em que Adão nomeia o mundo: “Então o Senhor Deus formou da terra todos os animais selvagens e todas as aves do céu, e os trouxe ao homem para ver como os chamaria; cada ser vivo teria o nome que o homem lhe desse. E o homem deu nomes a todos os animais domésticos, às aves do céu e a todos os animais selvagens" (GÊNESIS: 2; 19-20). A palavra adamítica, por sua vez, toma o mundo como referente. Com efeito, Adão atua no sentido oposto de Deus - uma vez que, para cada ser vivo, inventa um nome - uma palavra que será usada pela primeira vez, logo, a sua palavra

\footnotetext{
"Uma existência que não tivesse nenhuma relação com a linguagem é uma ideia; mas nem mesmo no domínio daquelas ideias que definem, em seu âmbito, a ideia de Deus, uma tal ideia seria capaz de se tornar fecunda" (BENJAMIN, 2011, p. 51)
}

cria a linguagem e a ordena. Deus cria o mundo a partir da palavra; Adão cria a palavra a partir do mundo. Deus é o Criador de todas as coisas, Adão é o Poeta que dá nome ao mundo, ${ }^{2}$ tornando diáfano o concreto, comunicando-se com Deus, criando 'a poesia que cria': poiesis. 0 primeiro homem foi, portanto, o primeiro poeta.

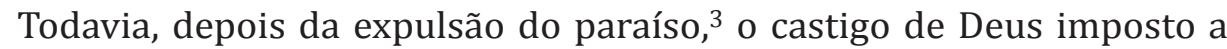
Adão era de que teria de comer o pão com o suor do rosto, até voltar à terra, donde foi tirado. Após a Queda, palavra não deve mais se voltar a si mesma, mas necessariamente ser funcional, comunicar algo a alguém. Ou seja, a poiesis torna-se uma afronta a Deus. Quem se dedicasse à poesia pagaria um preço alto por isso, pois a poiesis é a violação dos valores e das formas, é resistência à interdição divina. Em vista disso, todo o fazer poético é uma tentativa de retornar ao Paraíso Perdido, ${ }^{4}$ ainda que pelas portas do fundo.

Conquanto não estivesse mais no Éden, o homem ainda temia a Deus, por isso, não violou suas restrições. A poesia retornou apenas na geração seguinte - com os filhos de Caim, o fratricida proscrito. Mas quando o filho do primeiro poeta se tornou um amaldiçoado? Voltemos, pois, a Gênesis: "Caim

2 "[...] a essência linguística do ser humano é a sua língua. Isso quer dizer que o homem comunica sua própria essência espiritual na sua língua. Mas a língua do homem fala em palavras. Portanto, o ser humano comunica sua própria essência espiritual (na medida em que ela seja comunicável) ao nomear todas as outras coisas. [...] a essência linguística do homem está no fato de ele nomear as coisas" (BENJAMIN, 2011, p. 54-55).

3 A propósito da linguagem humana após a "Queda", Benjamin afirma: "O saber sobre o que é bom e o que é mau não tem a ver com o nome, é um conhecimento exterior, a imitação não criativa da palavra criadora. Nesse conhecimento, o nome sai de si mesmo: o pecado original é a hora de nascimento da palavra humana, aquela em que o nome não vivia mais intacto, aquela palavra que abandonou a língua que nomeia, a língua que conhece, pode-se dizer: abandonou a sua própria magia imanente para reivindicar expressamente seu caráter mágico, de certo modo, a partir do exterior. A palavra deve comunicar alguma coisa (afora si mesma). Esse é realmente o pecado original do espírito linguístico. A palavra que comunica do exterior, expressamente mediada, é de certa forma uma paródia da palavra imediata; é também a queda do espírito adâmico, do espírito linguístico bem-aventurado, que se encontra entre ambos" (2011, p. 67).

4 A propósito do Hipérion, de Hölderlin, Octavio Paz escreve: “Hipérion não luta apenas pela liberdade da A proposito do Hipérion, de Holderlin, Octavio Paz Grécia, mas também pela instauração de uma socién implica assim um regresso à poesia. A palavra poética é uma mediação entre o sagrado e os homens, 
apresentou ao Senhor frutos da terra como oferta. Abel, por sua vez, ofereceu os primeiros cordeirinhos e a gordura das ovelhas. E o Senhor olhou para Abel e sua oferta, mas não deu atenção a Caim e sua oferta. Caim se enfureceu e ficou com o rosto abatido" (GÊNESIS: 4; 3-5). Inconformado com a recusa de Deus diante de sua oferta, que era inclusive superior do que à de Abel, Caim assassina o irmão mais novo.

Ora, não há dúvida de que a oferta do primeiro é superior à do segundo: quer seja porque o resultado de seu labor se dava sem o derramamento do sangue dos cordeiros, quer seja porque o trabalho na terra ${ }^{5}$ era mais penoso e suado do que o pastoreio. Contudo, o senso comum tem perpetrado uma mistificação milenar, segundo a qual Caim teria matado o irmão por ciúme e inveja, quando, na verdade, o assassínio é praticado em razão da arrogante recusa de Deus. Deus despreza Caim e enaltece Abel, glorifica a facilidade e desdenha da honradez do trabalho duro. Caim pretende, pois, ao matar Abel, demonstrar que é superior à prepotência do Senhor. Mas, em resposta por sentir ferido o orgulho, Deus vinga-se de Caim.

Depois de ter assassinado o seu irmão Abel, Caim recebeu o maior castigo que se pode impingir a um ser humano; disse-lhe Deus: "Quando cultivares o solo, negar-te-á o sustento e virás a ser um fugitivo, errante sobre a terra" (GÊNESIS: 4; 12). Caim implora, então, ao Senhor que alivie o seu castigo. Em resposta às suas súplicas, Deus, em um ato de grande generosidade, abranda a pena do amaldiçoado, estipulando que seja vingado sete vezes aquele que o matar. Ademais, "o Senhor pôs, então, um sinal em Caim" (GÊNESIS: 4; 15); Caim se torna um proscrito, um assinalado, um amaldiçoado. 0 preço pago por defender a sua superioridade ante o Criador foi o banimento para Leste do Éden. 5 Vale lembrar que, no capítulo 3 da Gênesis, Deus castiga Adão com os seguintes dizeres: "amaldiçoada
será a terra por tua causa. Com fadiga tirarás dela o alimento durante toda a vida". Talvez porque Caim
seja lavrador, Deus tenha recusado a sua oferta. Caberia assinalar um parentesco entre o lavrador e o
poeta, entre Caim e Adão, visto que Adão nasce da terra, e Caim cultiva terra: ambos são filhos do barro. Para a relação entre os filhos do barro e poesia, sugiro ver Octavio Paz (2013).
Procurei demonstrar, nessa breve interpretação dos quatro primeiros capítulos da Gênesis, a estrita relação entre poesia e transgressão, bem como a maneira como os que se rebelam contra a Ordem opressora têm sido punidos desde a criação do mundo. Sou consciente de que se trata de uma parábola, mas não tenho dúvidas também de que a História do mundo é a repetição eterna da transgressão e do castigo. A poesia como violação da ordem vigente é, sem dúvida, um dos principais motivos da literatura romântica. Vale lembrar que, assim como Lúcifer, o assassino de Abel se tornou verdadeiro herói dos poetas do romantismo. Lord Byron, inclusive, escreveu um drama em sua homenagem: Caim (1821). Séculos antes de Byron, John Milton exaltou a beleza e virilidade de Lúcifer no seu Paraíso Perdido. "Better to reign in Hell than to serve in Heaven", diz o herói demoníaco de Milton. Caim e Lúcifer são o símbolo da rebeldia, da rebelião, da insubordinação; afinal, Lúcifer não se curva diante de Deus: "Non serviam" (Jeremias: 2; 20). Apesar da corajosa resistência, Lúcifer e Caim são derrotados. A revolução fracassa. O castigo pela petulância e insubmissão dos rebeldes: o Inferno para Lúcifer, e o exílio para Caim.

\section{Transgressão à ordem burguesa}

É no romantismo que surge o conceito do poeta como um ser superior, como um gênio cuja inspiração lhe é inata; enfim, um homem dotado de dons superiores, um indivíduo cuja capacidade criadora lhe fora transmitida ao nascer. 0 poeta-gênio é o mediador entre o Eu e a natureza, entre o ideal e o real ou, para seguir a fórmula dramática de Victor Hugo, entre o grotesco e o sublime. Com efeito, é no romantismo que se estabelece tanto a noção de um criador original que nega a tradição clássica quanto a de um indivíduo refratário às convenções sociais, encarnando uma revolta estética e também ética. Nas palavras de Benedito Nunes, 
O pathos da rebeldia, implícito ao individualismo egocêntrico, desse desejo insatisfeito e indefinido, sublinhou-se no satanismo, transformando a sede de conhecimento e poder na causa de um conflito dramático de proporções teológicas, pelo qual o homem não é o único agente responsável. Como potência espiritual externa de atuação ambígua, maléfica e benéfica, de que o homem se aproxima, com quem pactua por vontade própria, e contra quem se debate, Lúcifer, anjo caído e acólito de Deus, instiga a sede do poder e do conhecimento [...]. Adversário e aliado, antagonista necessário que transfigura a árvore do Bem e do Mal na árvore da vida, ao encorajar o homem a, infringindo as interdições do Deus-Pai, defrontar-se com o seu destino e com a morte, Satã, fonte do vigor do espírito e da imaginação para William Blake, "aquele que fala aos homens nos desejos do coração e nos sonhos da alma" (Vigny), é o símbolo maior da sequiosidade ambivalente da alma romântica, de sua introversão, de seu desdobramento interno, do conflito entre as suas aspirações ideais e a sua impotência real. (NUNES, 1993, p. 73)

Tem-se, portanto, imbricados o satanismo, a revolta e a sede de conhecimento; tudo isso condensado na figura do gênio criador. Vale lembrar que, quando o conceito de gênio surge no final século XVIII, é também o período em que o mundo sofre grandes transformações: a Revolução Industrial, na década de 1760; a Independência dos Estados Unidos, em 1776; a Revolução Francesa, em 1789. Ademais, o Iluminismo, sob a égide de Voltaire, Montesquieu, John Locke etc., e o Liberalismo, que se tornou manual de economia com Adam Smith, exerciam enorme influência em praticamente todos os setores da sociedade. O Iluminismo, que evoluiu para o Positivismo no final do século XIX, fazia de Logos o seu Deus, da Razão, a sua religião. ${ }^{6}$ Trata-se, portanto, do triunfo da modernidade, da razão instrumental e da burguesia: tudo aquilo contra o que a sensibilidade romântica se insurgia.

\footnotetext{
${ }^{6}$ Romain Rolland satiriza os fanáticos da Razão em seu romance Jean-Christophe: "É verdade que sua liberdade de pensamento consistia em proibir a dos outros em nome da Razão: porque acreditavam na Razão como os católicos acreditam na Virgem Santa, sem suspeitarem, uns e outros, que a na Raz̃̃o cono os católicos a Vreditam na vírgem Santa, se suspeitarem, pé outros, que a (1986, p. 136).
}

O satanismo romântico repercute na forma como Deus é vulgarmente compreendido, isto é: Deus é, por vezes, o Progresso e, por vezes, o atraso. ${ }^{7}$ E os poetas ora $\mathrm{O}$ celebram, ora $\mathrm{O}$ execram. Celebram-no: Deus representa o Absoluto, o elemento transcendente - em detrimento de uma sociedade materialista e pragmática. Execram-no: Deus é identificado com o ancien régime ou com a ordem burguesa, personifica a ética protestante - sendo que, numa sociedade onde o tempo é sinônimo de dinheiro, não se pode desperdiçar horas contemplando a natureza, as pessoas, o mundo. Essa ambiguidade em relação a Deus é retomada ad nauseam na poesia do romântico tardio Charles Baudelaire. Para os artistas da época, Deus representa a opressão, o establishment e a civilização; Satã é a rebeldia, a liberdade, a natureza.

Estabelece-se, também, uma dicotomia entre a vita contemplativa e a vida prática, entre mundo interior e mundo exterior; em suma, entre o artista e o burguês. Em Passagens, Walter Benjamin afirma que "na sociedade burguesa, a preguiça [...] tinha deixado de ser 'heroica'” (BENJAMIN, 2006, p. 840). E continua:

Na sociedade feudal, o ócio - a desobrigação do trabalho - era um privilégio reconhecido. Na sociedade burguesa não é mais assim. 0 que distingue o ócio, tal como o conhece o feudalismo, é o fato de ele se comunicar com dois tipos importantes de comportamento social. A contemplação religiosa e a vida na corte representam, por assim dizer, as matrizes em que podia ser moldado o ócio do nobre, do prelado, do guerreiro. Estas atitudes - tanto a da piedade quanto a da representação - traziam vantagens ao poeta. Sua obra as favorecia pelo menos indiretamente, ao preservar o contato com a religião e com a vida na corte. [...] Na sociedade feudal, o ócio do poeta é um privilégio reconhecido. É somente na sociedade burguesa que o poeta é considerado como alguém que vive na ociosidade. (BENJAMIN, 2006, p. 842)

7 “Negação da religião: paixão pela religião. Cada poeta inventa sua própria mitologia e cada uma dessas mitologias é uma mistura de crenças díspares, mitos desenterrados e obsessões pessoais. [...] Religiões
românticas: heresias, sincretismos, apostasias, blasfêmias, conversões. [...] O tema da morte de Deus é românticas: heresias, sincretismos, apostasias, blasfêmias, conversões. [...] 0 tema da morte de Deus é um tema romântico. Não e um tema filosófico, e sim religioso. Para a razão, Deus existe ou não existe. No primeiro caso, não pode morrer, e no segundo - como pode morrer alguém que nunca existiu?"
(PAZ, 2013, p. 54). 
Além disso, o poeta é cada vez mais segregado, exilado, abrindose também uma fissura na linguagem poética, pois se, durante o período do triunfo da burguesia, prevaleceu uma escrita única, instrumental e ornamental (BARTHES, 2000); com a perda das ilusões do liberalismo, decorrente da malograda Revolução de 1848, a qual condena o intelectual ao papel de consciência infeliz da sociedade, não sendo mais o seu portavoz, a literatura não fala mais por meio do universalismo da escrita clássica, instrumental; ela é plural, multiforme. Se o poeta era visto como louco e perdulário, por se voltar às coisas transcendentes e não às coisas práticas; agora, isso se acentua, muito embora se cultive, a partir de então, um artesanato do estilo, assumindo-se um valor-trabalho no ofício literário (BARTHES, 2000). Ora, uma vez que o poeta não se adapta à vida prática, torna-se um corpo estranho. Por não se dedicar a trabalhos corporais, é visto como um preguiçoso; por não se importar com o dinheiro, um louco. 0 poeta é um exilado.

O poeta não se sente em casa porque o mundo lhe limita e lhe diminui; porque o seu reino não é deste mundo, porque ele é maior e nasceu para coisas mais elevadas do que ser escravo do próprio corpo. Ele anseia pelo infinito, mas se sente limitado à sua condição - social, fisiológica, histórica etc. 0 mundo é, para ele, a negra algema de que fala Cruz e Sousa no soneto "O Assinalado". Quando falo de poeta, estou me referindo também a outros artistas que sofrem a maldição do exílio: Van Gogh e Caravaggio, na pintura; Chopin e Beethoven, na música; Orson Welles e Jean Vigo, no cinema - apenas para me limitar a alguns nomes. Mas é na poesia que a maldição fez mais vítimas. Digo poesia em um sentido geral, pois tanto romancistas quanto alguns filósofos poderiam integrar o rol dos poetas malditos.

Muitos poetas celebrados, hoje em dia, foram marcados em suas frontes com o ferro em brasa pelo mesmo Deus que baniu Caim, deixandolhes cicatrizes indeléveis. Na novela Tonio Kroeger, de Thomas Mann, a personagem homônima diz: "Estou entre dois mundos; não me sinto à vontade em nenhum dos dois e por isso tenho um pouco de dificuldade" (MANN, 1971, p. 84). E sentencia:

A literatura não é profissão alguma, e sim uma maldição - que saiba disso. Quando é que começa a se fazer sentir essa maldição? Cedo, terrivelmente cedo. Em um tempo quando facilmente ainda se pode viver em paz e harmonia com Deus e com o mundo. Você começa a se sentir marcada, num contraste misterioso para com os outros, os comuns, os cordeiros; o abismo da ironia, da descrença, da oposição, da cognição, do sentimento, que a separa dos homens, torna-se mais e mais profundo, está isolada e daí em diante não há mais entendimento. (MANN, 1971, p. 40)

De um lado, os ociosos, os artistas; do outro, os pragmáticos, os burgueses. Assim, o poeta e o burguês reencenam o drama da parábola de Abel e Caim. Caim, novamente, oferta a Deus um presente sublime, mas é rejeitado por Ele, que prefere, mais uma vez, a mediocridade da oferta de Abel. A raça de Abel faz zombarias da raça de Caim, insultando-a, humilhando-a, constrangendo-a a ter de vagar à cata de esmolas para comprar o próprio pão. Caim escolhe o exílio por conta própria - pois não consegue viver mais entre os homens.

Mas a maldição só se torna maldição por causa da solidão, da condição de outsider. Gênios, ${ }^{8}$ não há muitos. Poucos que já estiveram sobre a terra merecem esse nome. Gênio é exceção. Com efeito, não vemos os gênios andando por aí, pois eles são arredios, não se exibem, têm vergonha do sinal marcado em sua fronte. Genialidade é anormalidade, é doença, melancolia. A maldição consiste em ser o outro, o desvio, o anormal, o intruso - e o que é pior: ter consciência disso.

${ }_{8}^{8}$ Valho-me, aqui, do parentesco apontado pelos românticos entre o poeta e o gênio. 


\section{Doença e Melancolia}

Aristóteles, em seu notório "O problema XXX", faz a seguinte indagação: "Por que razão todos os que foram homens de exceção, no que concerne à filosofia, à ciência do Estado, à poesia ou às artes, são manifestamente melancólicos?" (ARISTÓTELES, 1998, p. 81). A resposta dada por ele atribui a melancolia a causas fisiológicas, como a bile negra - o que não é de nosso interesse. Com efeito, não interessa a resposta, o fascínio de sua proposição reside na pergunta; aliás, não estaria a resposta na própria pergunta? 0 homem de exceção é melancólico justamente por ser um homem de exceção. O homem excepcional representa um desvio da norma, do padrão. Ele é um indivíduo anormal, um outsider.

Ora, todo aquele que se percebe diferente dos outros, que é excluído em virtude de sua diferença, termina por se isolar do mundo. Priva-se do contato dos outros homens, não compartilhando, portanto, dos mesmos interesses, nem sentindo os mesmos prazeres ou fraquezas. Mas, como o próprio Aristóteles postulara, o homem é um "animal social" que tem a necessidade inata de se comunicar com os demais, de partilhar experiências ou simplesmente conviver em comunidade. Uma vez que, por sua diferença, é excluído do contato com os outros, ele torna-se melancólico. A não-aceitação pelos outros se converte em não-aceitação de si mesmo. Mas é a melancolia que o torna uma exceção ou o fato de ser uma exceção que o torna melancólico? De fato, ambas as proposições estão corretas. A melancolia é mãe e filha do gênio. Assim, há de se admitir que sua genialidade é inata. Walter Benjamin, comentando sobre aqueles nascidos sob o signo de Saturno, afirma:

[...] a meditação do melancólico é compreendida na perspectiva de Saturno, que "como o planeta mais alto e o mais afastado da vida cotidiana, responsável por toda contemplação profunda, convoca a alma para a vida interior, afastando-a das exterioridades, leva-a a subir cada vez mais alto e enfim inspira-lhe um saber superior e o dom profético". [...] Como a melancolia, também Saturno, esse demônio das antíteses, investe a alma, por um lado, com preguiça e apatia, por outro com a força da inteligência e da contemplação. (1984, p. 171-172)

Todo gênio é melancólico, mas nem todos os melancólicos são necessariamente geniais. Privar-se do convívio humano também não significa que se é genial, porquanto nem todo misantropo ou eremita é um gênio criador. E os gênios alegres? E a alegre sabedoria do melancólico Nietzsche? o simples fato de saber-se um indivíduo extraordinário entristece o gênio. Gênio é melancolia.

Não apenas a doença espiritual - a melancolia - como também os transtornos físicos são responsáveis pela formação do indivíduo genial. Sem dúvida, as doenças que mais fizeram vítimas entre os gênios românticos foram a tuberculose e a sífilis. É uma mórbida coincidência o fato de muitos poetas brasileiros terem morrido vitimados pela mycobacterium tuberculosis, tais como: Castro Alves, Casimiro de Abreu, Álvares de Azevedo, Augusto dos Anjos, Cruz e Sousa e Manuel Bandeira. O romancista tcheco Franz Kafka, bem como o compositor polonês Frédéric Chopin e o poeta alemão Friedrich Schiller padeceram, igualmente, da "peste cinzenta".

Outra enfermidade que assolou alguns gênios do século XIX foi o popular "mal francês": a sífilis. Friedrich Nietzsche, Tolstói, Franz Schubert, E.T.A. Hoffman, Heinrich Heine, Oscar Wilde e Charles Baudelaire foram vítimas dessa doença. Alguns transtornos mentais também integram a lista das doenças de que os gênios padeceram. Na carta de suicídio de Virginia Woolf, a escritora afirma que ouvia vozes, que acreditava estar ficando louca e que sofria de uma doença terrível. Segundo estudos hodiernos, ela sofria de esquizofrenia. O grande poeta italiano Giacomo Leopardi teria sofrido de transtorno bipolar, além de tuberculose na coluna vertebral (o chamado mal de pott). Vincent Van Gogh teria sofrido de sífilis, esquizofrenia, epilepsia e transtorno bipolar. Ora, mas qual é a relação entre essas doenças e a genialidade? 
No magistral romance $A$ Montanha Mágica, Thomas Mann recria a Belle Époque num sanatório em Davos, na Suíça, onde diversos enfermos se restabelecem da tuberculose. A partir da noção de "lá em cima" (no sanatório) e "lá em baixo" na planície, Thomas Mann recria a dicotomia entre espírito e vida, entre doença e sanidade. Com efeito, é retomada a bifurcação goethiana em Wilhelm Meister entre o grande mundo (vida em sociedade) e o pequeno mundo (vida espiritual). Em A Montanha Mágica, a doença torna-se sinônimo de espírito puro - ideal que é combatido pela personagem humanista, alterego de Mann, Settembrini.

O protagonista Hans Castorp, fascinado por esse elemento mórbido e irracional, diz: "A doença é, por assim dizer, uma coisa digna de reverência. [...] Sempre se pensa que uma pessoa estúpida deve ser sadia e comum, e que a doença torna as criaturas finas e cultas e diferentes" (MANN, 2006, p. 136-137). A despeito de sua ironia ao se referir aos tolos com que convive e que são doentes, Hans vê como inconciliáveis a estupidez e a doença. A doença, para ele, torna mais agudo o espírito, fazendo com que o enfermo perceba coisas que a pessoa sadia jamais compreenderia. Obviamente, não é a doença que, ao atuar no corpo, modifica a fisiologia de um indivíduo a ponto de fazer com que seu cérebro se desenvolva mais do que o das pessoas sãs, mas sim o fato de uma pessoa doente ter de se isolar das demais, quer seja por medidas preventivas para combater o contágio da doença, quer seja porque o indivíduo enfermo envergonha-se de sua condição e prefira o isolamento. Como já foi dito, a solidão é a condição sine qua non do gênio, não devendo, no entanto, ser confundida com misantropia ou eremitagem.

Outro fator que faz com que a doença atue sobre o gênio é a consciência da morte, ou seja, consciência de si mesmo. Os indivíduos doentios - pelo menos os que sofrem de doenças fatais - não veem a morte no horizonte longínquo de sua existência, mas como um fantasma bem real que se aproxima cada vez mais depressa. A morte não é mera abstração para o enfermo; ela existe em sua facticidade. Com efeito, essa certeza sobre a própria finitude faz com que o indivíduo extraordinário compreenda a vanidade de todas as coisas.

Uma vez que se percebe mortal e toma consciência de si mesmo, o gênio galga um degrau da sabedoria que muitos homens morrem sem jamais cogitar subi-lo. A certeza perene da própria morte - ou seja, a consciência da sua própria condição - equivale ao conhece-te a ti mesmo inscrito nos pórticos do Oráculo de Delfos. Genialidade é também consciência de si mesmo. 0 gênio volta-se para si mesmo e compreende a condição humana. Ele olha para os olhos da Górgona, mas não se petrifica - ele zomba daquilo que vê, zomba de sua monstruosidade, traz à luz os seus demônios interiores: os seus medos, as suas dores, a sua morte. Autoconsciência é saber que se sabe, é conhecer a sua finalidade única, é olhar ao redor e intuir a verdade absconsa. $\mathrm{O}$ gênio isola-se em seu "pequeno mundo", cria o próprio universo moral, decodifica a verdade transformando-a em arte.

Mas, como lembra Virgílio: Facilis descensus Averno - de fato, o difícil é sair de lá. O processo de tomar consciência de si mesmo é uma longa e tortuosa descida aos infernos, de onde muitos sucumbem no caminho de volta. Nem todos voltam, pois se petrificam de terror. Autoconsciência é descer aos infernos, mas apenas o gênio sai de lá. Devido à experiência da morte, da dor e do mal, o gênio sai dos infernos fortalecido, e precisa relatar a sua experiência. Em suma, o gênio torna-se consciente de si mesmo devido à experiência da morte - a qual, muitas vezes, pode decorrer em virtude da doença.

Como já foi dito, a doença isola os indivíduos para que não haja contágio; aliás, a autoconsciência faz com que o indivíduo volte os olhos para dentro de si mesmo, pois o seu interior, o seu "pequeno mundo" causa-lhe fascínio. A solidão faz com que o gênio anseie ainda mais pela solidão. Ele quer estar sozinho - sozinho, como o Fausto fechado em seu gabinete estudando. A doença do corpo converte-se em doença da alma, o sofrimento físico 
converte-se em sofrimento espiritual. Pior do que a dor física é a dor espiritual. É isso o que quer dizer Eclesiastes ao afirmar que em muito conhecimento há muito sofrimento. 0 gênio - assim como o melancólico - sofre pelo simples fato de existir, pelo simples fato de estar-aí-no-mundo, mas, ao contrário deste, a sua angústia é transformada em arte. Assim, a doença atua por vias opostas com o propósito comum de tornar o gênio um homem solitário, um outsider, um anormal. O gênio é filho do casamento do morbo com a melancolia, é o feto abortado da cópula entre uma alma e um corpo enfermos. Gênio é degenerescência, é putrefação, é o Mal. O narrador de Doutor Fausto, de Thomas Mann, chega a afirmar a propósito da genialidade: "não se pode negar e nunca se negou que o elemento demoníaco, irracional, ocupa uma parcela inquietante dessa esfera luminosa" (MANN, 2000, p. 11).

\section{Dois casos malditos: Balzac e Rimbaud}

Os autores de que agora falarei são verdadeiros titãs, não há dúvida, mas irrita-nos o fato de que eles sabiam disso, de que a nós cabe apenas venerá-los. Nós, os tolos, esperávamos que fossem humildes e modestos, pois ninguém é capaz de suportar alguém que seja melhor que ele próprio. Contudo, vale ressaltar que o orgulho é uma das condições da grande arte, portanto, antes de acusá-los, devemos saudá-los.

A literatura ${ }^{9}$ e a modéstia são substantivos totalmente antitéticos. De fato, ela é a esposa mais bela do Orgulho; sendo, pois, inseparáveis. A

\footnotetext{
9 Para não incorrer no risco de generalizações, faço uma ressalva: quando me refiro à arte ou à literatura, tenho em mente o percurso desenvolvido neste ensaio, ou seja, trata-se de uma concepção romântica, algo demoniaca - a qual está presente na definição de Georges Bataille, em A literatura e o mal: "A literatura é o essencial ou não é nada. O Mal - uma forma penetrante do Mal - de que ela é expressão tem para nós, creio u, o valor soberano. Mas esta concepção não impõe a ausência de moral, exige uma hipermoral" (1989, p.10). Mais adiante, Bataille prossegue: "Somente a literatura poderia desnudar o jogo da transgressão da ei - sem o que a lei não teria fim - independentemente de uma ordem a criar. A literatura não pode assumir um perigo. Sendo inorgânica, ela é irresponsável. Nada de apoia nela. Ela pode dizer tudo" (1989, p. 22).
}

literatura não é um divertimento leve e descompromissado dos modestos, dos bons moços; ela é desconforto, é insatisfação. A literatura deve incomodar, tirar-nos de nossa zona de conforto. Não é remédio para nossas dores, é a agulha que espicaça nossas feridas até que voltem a sangrar. Não é o perfume das rosas, é o odor fétido dos esgotos. Se um livro nos diz palavras que nos confortam nos momentos de mais profunda angústia, devemos atirá-lo no lixo. A literatura deve ser como o médico que tem a honestidade de dizer ao paciente: "você não deve ter qualquer esperança". A literatura - que merece assim ser chamada - é egoísta, é arrogante, é vaidosa, embora despreze todos os elogios. Logo, o romancista e o poeta devem julgar-se ainda maiores do que são, devem ter consciência de que são os melhores, de que estão acima do bem e do mal.

A definição de literatura presente nos manuais é geralmente insatisfatória. Qualquer pessoa que possua um conhecimento incipiente sobre "a arte das palavras" sabe que a sua principal característica - não obstante a formulação que vai de Aristóteles a Auerbach sobre a mímesis - é a diferença em relação à linguagem corrente no cotidiano, ou seja, a linguagem literária possui uma finalidade em si mesma, não visando, portanto, comunicar alguma coisa (embora, na maioria das vezes, a função poética mostre-se mais eficiente que a função referencial ao transmitir determinado modo de pensar). Isso pressupõe que a linguagem literária possui uma especificidade, em que apenas algumas "criaturas iluminadas" - o gênio romântico, por exemplo são capazes de valer-se dela para comunicar aquilo que intencionam.

Em vez da modéstia, da humildade, do bom-mocismo, enfim, da mediocridade, o espaço literário é o da ambição, da concorrência, da soberba, do Mal. O Orgulho - o pecado de Lúcifer - deve ser a força motriz da literatura; afinal, o poeta/romancista só escreve porque está insatisfeito com o mundo em que vive, porque se julga capaz de fazer em um único verso aquilo que Deus malogrou fazer em sete dias. 
Tendo isso em mente, podemos ousar dizer que a literatura é uma maneira de competir com Deus, de modificar aquilo que o Criador teria feito de forma equívoca. Mas, como alguns escritores veem o mundo diferente de outros, esses homens que brincam de Deus, esses "portadores da luz", criam, à sua maneira, todas as potencialidades do universo - o que, em maior ou menor medida, sempre trará significativas transformações no mundo originalmente criado por Deus. Literatura não é apenas que poderia ter sido, é aquilo que deverá ser.

Porém, o que mais desperta fascínio dessa experiência malignamente sagrada de brincar de Deus, de espoliar o fogo em favor dos homens, assim como Prometeu o fez, é a altura em que se colocam esses deuses malditos, é o pedestal em que se colocam para observar-nos. Deve ter ocorrido a eles em algum momento a ideia de que são maiores e nascidos para coisas maiores do que se submeter à mediania, ao senso comum, à vala onde são enterrados aqueles que morrem para sempre, enquanto eles passam a viver em todo o esplendor quando se libertam do corpo degradante que limita às pulsões espirituais de seu gênio. Alguns exemplos disso são: a pretensão de Goethe no seu projeto da weltliteratur, bem como o anseio do Absoluto que roubou 60 anos de sua vida aplicados no Fausto; Flaubert e a sua crítica ao pensamento humano ao longo da História, em Bouvard e Pécuchet, além de sintetizar as possibilidades romanescas em A educação Sentimental; Victor Hugo e sua famosa frase no seu caderno de colegial, quando tinha apenas 14 anos: "Eu quero ser Chateaubriand ou nada".

Na literatura em prosa, o maior de todos foi, sem dúvida, Balzac, que disse, certa vez, que o seu propósito era realizar pela pena aquilo que Napoleão havia falhado em fazer pela espada. Em carta à Mme. Hanska, de 1844, afirmou: "Quatro homens tiveram uma vida imensa: Napoleão, Cuvier, O'Connell, e eu quero ser o quarto. O primeiro viveu a vida da Europa, e se inoculou exércitos! O segundo desposou o globo! O terceiro encarnou um povo! Eu carreguei uma sociedade inteira na cabeça!" (BALZAC apud RÓNAI, 1989,61 ). Essa sociedade harmonicamente infernal faz com que ele compare a sua obra à Comédia de Dante, tanto que a intitula A Comédia Humana, em contraposição à Divina Comédia. Diz o autor no L'avant-propos de la Comédie Humaine:

A imensidão do plano, que compreende ao mesmo tempo a história e a crítica da sociedade, a análise de seus males e a discussão de seus princípios, autorizame, assim o creio, a dar à minha obra o título sob o qual hoje ela aparece: $\mathrm{A}$ Comédia Humana. Será ambicioso? Não será apenas justo? É o que o público decidirá, quando a obra estiver terminada. $(2012, \mathrm{~s} / \mathrm{p})$

Assim, Balzac coloca-se ao lado de Dante Alighieri, o autor que fez a súmula civilizatória de sua época, pois sua intenção é fazer a análise mais completa já realizada sobre a vida moderna em seus estudos dos costumes, analíticos e filosóficos. Quando se delineia em sua mente o projeto megalomaníaco de representar a sociedade de seu tempo em uma obra, escreve à sua irmã: "Saudai-me, pois estou seriamente na iminência de tornar-me um gênio" (BALZAC apud RÓNAI, 1989, p. 46). Com efeito, o mundo de $A$ Comédia Humana é a representação mais perfeita da condição humana, na modernidade, onde todas as nossas pulsões mais nobres e mais vis encenam-se no pior dos mundos possíveis. Balzac recria o mundo à imagem e semelhança de si mesmo, fazendo não da realidade em-si, mas de suas potencialidades a matéria-prima para seus romances. A consciência de sua grandiosidade está presente em cada linha de sua obra, quando, hiperbolicamente, faz com que suas personagens sejam maiores do que de fato o são, como, por exemplo, ao comparar suas personagens a deuses, ou ao próprio Cristo e à Virgem. Isso foi visto como defeito por muitos intérpretes de sua obra, como Erich Auerbach, que afirma: 
Qualquer enredo, por mais trivial ou corriqueiro que seja, é por ele tratado grandiloquentemente, como se fosse trágico; qualquer mania é por ele vista como paixão. Está sempre disposto a marcar qualquer infeliz como herói ou como santo; se se tratar de uma mulher, compara-a com um anjo ou com uma madona. Demoniza todo e qualquer malvado vigoroso e, em geral, qualquer figura levemente sombria; e chega até a chamar o coitado do velho Goriot ce Christ de la paternité. (AUERBACH, 2004, p. 431)

Em um curioso ensaio sobre Balzac, Anatole France (1954, s/p) afirma:

Há imagens mil funestas do que as imagens esculpidas e pintadas, das quais Jeová quis preservar Israel: são as imagens por excelência, as imagens ideais que os romancistas e os poetas concebem. São os tipos e caracteres, são as personagens dos romances. Essas figuras vivem uma vida ativa; são almas e é justo dizer que os seus malignos autores as lançam entre nós como demônios para nos tentar e perder. E como escapar-lhes, pois que elas habitam em nós e nos possuem? Goethe lança Werther no mundo e logo os suicídios se multiplicam. Todos os poetas, todos os romancistas, sem exceção, perturbam a paz da terra. A Ilíada de Homero e o Germinal de Zola produziram igualmente crimes. Emílio fez terroristas e assassinos daqueles que Jean-Jacques queria reconduzir à natureza. Os mais inocentes, como Dickens, são ainda assim grandes culpados; desviam para seres imaginários a nossa ternura e a nossa piedade, que estariam colocados sobre a cabeça dos vivos que nos rodeiam. Tal romancista produz histéricos, tal outro faz coquetes, um terceiro, jogadores e assassinos. Porém o mais diabólico de todos, o Lúcifer da literatura, é Balzac. Ele imaginou todo um mundo infernal que realizamos hoje. É de acordo com os seus planos que somos ciumentos, cúpidos, violentos, agressivos e que nos arremessamos uns sobre os outros, com uma fúria homicida e ridícula, à conquista do ouro, ao assalto das honras. Balzac é o príncipe do mal e o seu reino chegou. Por todos os escultores, por todos os pintores e todos os poetas, por todos os romancistas que desde os primeiros tempos do mundo, até esta hora, fizeram mal à humanidade, Balzac seja maldito!

O Grande Inquisidor teria ordenado a Jesus Cristo que retornasse ao Céu, pois, apesar de tudo, os homens construíram uma civilização; entretanto, quando Lúcifer fez sua última aparição, como um jovem provinciano de Charleville, no final do século XIX, permitiu que este permanecesse na terra para cumprir os seus intentos. O enfant terrible Arthur Rimbaud fez em três anos aquilo que nenhum poeta jamais havia logrado fazer e que nenhum outro provavelmente conseguirá fazer novamente. Entre os 16 e 19 anos, Rimbaud escreveu pelo menos três obras-primas: Le Bateau Ivre, Une Saison en Enfer e Les Illuminations, além de outros poemas de originalidade nunca antes vista. Sua vida foi um escândalo, sua obra um escândalo ainda maior, mas é o seu silêncio que nos choca realmente. 0 poeta diz em certa passagem de Une Saison en Enfer: "Eu tenho todos os talentos! Não há ninguém aqui e há alguém: não queria desperdiçar meu tesouro". ${ }^{10}$ É como se nos dissesse: $E u$ posso fazer tudo quanto quiser; não há ninguém que faça poesia melhor do que eu, no entanto, vou me calar - não encontrei nenhum justo que mereça esse meu tesouro! Porquanto não quer jogar suas pérolas aos porcos, prefere o silêncio, o não.

Rimbaud oferece às feiticeiras, à miséria, ao ódio o seu tesouro; ataca a alegria como um animal feroz, diviniza a desgraça e, em vez de invocar as musas, conjura Satã e lhe dedica o seu livro hediondo. Ele atribui ao sangue de seus antepassados a sua falta de traquejo com a vida prática; odeia todas as profissões, tem verdadeira aversão ao trabalho, pois a honradez da mendicidade lhe exaspera. A postura iconoclasta do vidente de Charleville está sintetizada nesses versos: "A quem me alugar? Que besta é preciso adorar? Que santa imagem atacar? Que corações destruirei? Que mentira devo sustentar? Sobre que sangue marchar?"11

Ele procura um lugar em que possa oferecer o seu gênio, mas todas as portas lhe são fechadas na cara. Ele louva e espera conforto em Deus, porém, mata o Evangelho. A razão lhe desperta, mas não lhe torna prisioneiro. Rimbaud é sempre mais do que si mesmo: "Eu é um outro", ${ }^{12}$ diz ele na Carta

${ }^{10}$ RIMBAUD, 1998, p. 148, tradução minha.

11 RIMBAUD (1998, p. 138). Tradução minha.

12 RIMBAUD (2009, p. 38) 
do Vidente. Primeiro, senta a beleza sobre o joelho e a injuria; depois, aprende a saudá-la. Quer ser feliz a todo custo, mas despreza a felicidade estabelecida e doméstica; é incapaz de amar, mas quer ser amado indiscriminadamente. Nesse turbilhão de vontades e sensações, o que o guia é sua intuição, sua vidência: "Vou desvendar todos os mistérios: mistérios religiosos ou naturais, morte, nascimento, futuro, passado, cosmogonia, o nada. Sou mestre em fantasmagorias".13 A sua pretensão fáustica vai além: reinventa o amor, inventa cores para as vogais, anota o inexprimível, fixa as vertigens, torna-se simultaneamente homem e mulher, funde a verdade em um só corpo e alma. Rimbaud encontrou a Eternidade!

Em sua descida aos infernos, ele transfigurou o sentido de tudo. 0 mundo não é mais o mesmo, a poesia já não é mais a mesma. "É preciso ser absolutamente moderno"14, "é preciso ser vidente, fazer-se vidente". 15 Rimbaud sabe de suas conquistas e de suas limitações:

Eu criei todas as festas, todos os triunfos, todos os dramas. Experimentei inventar novas flores, novos astros, novas carnes, novas línguas. Acreditei adquirir poderes sobrenaturais. Pois bem! devo enterrar minha imaginação e minhas lembranças! Que bela glória de artista e narrador arrebatada! Eu! eu que me dizia mago ou anjo, dispensado de toda a moral, estou rendido ao chão, com um dever a procurar e a áspera realidade a abraçar. ${ }^{16}$

Como Prometeu, rouba o fogo dos deuses, mas, enquanto a águia lhe devora o fígado, gargalha da própria dor e daqueles que sentem compaixão por si. $O$ poeta nos remete, na primeira parte das Iluminações, à famosa frase de Luís XV: "Depois de mim, o Dilúvio". Com efeito, depois de Rimbaud, o mundo ficou em pedaços, acabou-se a paz sobre a terra. Maldito seja!

${ }^{13}$ RIMBAUD (1998, p. 148). Tradução minha.

${ }^{14}$ RIMBAUD (1998, p. 190). Tradução minha.

${ }^{15}$ RIMBAUD (1998, p. 190).

${ }_{16}^{16}$ RIMBAUD (1998, p. 188). Tradução minha.

\section{Considerações finais}

No poema "Abel e Caim" - que integra o ciclo "Revolta", d'As flores do mal -, Charles Baudelaire desenvolve, uma contraposição entre os indivíduos da raça de Caim e da raça de Abel, mantendo clara simpatia pelos filhos de Caim, que é o primeiro maldito, o símbolo dos oprimidos. Engana-se, porém, quem formula, a partir dessa antítese, a luta de classes entre a burguesia e o proletariado; antes, os deserdados de quem fala o eu-lírico baudelairiano referem-se às prostitutas, aos ladrões, aos mendigos, aos "anormais", aos poetas, enfim, aos marginalizados da sociedade. Sendo descendente de Caim, o poeta é, essencialmente, um maldito, um outsider, um exilado.

Evidentemente, o modelo de poeta com quem Baudelaire encontra parentesco é o poeta romântico, aquele que é refratário às convenções sociais, que se revolta e se melancoliza por causa da posição a que foi relegado. Os descendentes de Caim são revoltados, e a literatura que produzem é cheia de fúria, de arroubos, de paixões extremas, de liberdade, de irracionalidade, de dionisíaco, de tudo quanto os filhos de Abel tentam a todo custo reprimir, encarcerar, manter sob controle. Mas os descendentes da Caim, inspirados por Lúcifer, sempre se rebelam, rompem as correntes e escapam das prisões do tédio e das trevas. Em A dupla chama, Octavio Paz descreve esse movimento de repressão e libertação do "portador da luz":

No centro da negritude absoluta do mal apareceu um reflexo indeciso: a luz vaga do amanhecer. Lúcifer: começo ou queda, luz ou sombra? Talvez um e outro. Os poetas perceberam essa ambiguidade e tiraram o partido que conhecemos. Lúcifer fascinou Milton mas também os românticos, que o converteram no anjo da rebeldia e no portador da tocha da liberdade. As manhãs são breves e mais breves ainda as iluminadas pela luz ziguezagueante de Lúcifer. Apareceu ao despontar do século XVIII e na metade do século XIX empalideceu seu rubro esplendor, embora tenha continuado iluminando com uma luz tênue e perolada, luz do pensamento mais que do coração, o longo entardecer do simbolismo. [...] A modernidade teve duas manhãs: uma, a que viveu Hegel e 
sua geração, que começa com a Revolução Francesa e termina 50 anos depois; a outra, a que se inicia com o grande despertar científico e artístico que precede a primeira guerra mundial e termina ao eclodir a segunda guerra. 0 emblema desse segundo período é, outra vez, a figura ambígua de Lúcifer. Anjo do mal, sua sombra cobre as duas guerras, os campos de Hitler e Stálin, as explosões de Hiroshima e Nagasaki; anjo rebelde da luz, é a fagulha que acende todas as grandes inovações de nossa época na ciência, na moral e nas artes. De Picasso a Joyce e de Duchamp a Kafka, a literatura e a arte da primeira metade do século XX foram luciferinas. (PAZ, 1994, p. 133-134)

Depois do brilho intenso das vanguardas na aurora do século XX, Lúcifer retirou-se. Isso não significa que deixou de existir a arte ou a literatura, mas sim que "não as ilumina a luz ambígua e violenta de Lúcifer: são obras crepusculares" (PAZ, 1994, p. 136). Para que a luz luciferina irradie em nosso século, os filhos de Caim deverão abandonar os seus temores e aceitar o convite de Lúcifer para descer nos Hades, a fim de obter a sabedoria sobre a vida e a morte - tal como narra Lord Byron, no seu Cain. ${ }^{17}$ Assumindo que uma literatura autêntica necessita do demoníaco e do irracional, é que se dissipará as brumas do tédio que caracteriza o nosso mundo hoje. Como diz Bataille: "A literatura não é inocente, e, culpada, ela enfim deveria se confessar como tal" (1989, p. 10); afinal, retomando o que foi dito no início deste ensaio, o próprio fazer poético é, por si só, uma violação ao interdito divino.

\section{Referências}

ARISTÓTELES. O homem de gênio e a melancolia: o problema XXX. Trad. Alexei Bueno. Rio de Janeiro: Lacerda, 1998.

AUERBACH, Erich. Mimesis: a representação da realidade na literatura ocidental. 5. ed. São Paulo: Perspectiva, 2004.

\footnotetext{
${ }^{17}$ Diante da hesitação de Caim, Lúcifer o exorta: "Fear not - without me thou couldst not have gone beyond thy world" (BYRON, 1830, p. 229).
}

BALZAC, Honoré. Prefácio à Comédia Humana. In: . A Comédia Humana: estudos de costumes: cenas da vida privada. 3. ed. Trad. Vidal de Oliveira. São Paulo: Globo, 2012.

BARTHES, Roland. O grau zero da escritura: seguido de novos ensaios críticos. Trad.: Mário Laranjeira. São Paulo: Martins Fontes, 2000.

BATAILLE, Georges. A literatura e o mal. Trad. Suely Bastos. Porto Alegre: L\&PM, 1989. BENJAMIN, Walter. Origem do drama barroco alemão. Trad. Sérgio Paulo Rouanet. São Paulo: Brasiliense, 1984.

Passagens. Trad. Irene Aron e Cleonice Paes Barreto Mourão. Belo Horizonte: Editora UFMG; São Paulo: Imprensa oficial do Estado de São Paulo, 2006.

Sobre a linguagem em geral e sobre a linguagem do homem. In: Escritos sobre mito e linguagem. Organização, apresentação e notas de Jeanne-Marie Gagnebin. Trad. de Susana Kampff Lages e Ernani Chaves. São Paulo: Editora 34; Duas Cidades, 2011.

BÍBLIA. Português. Bíblia Sagrada. 36. ed. Trad. Ludovico Garmus. Petrópolis: Vozes, 1982.

BYRON, George Gordon. Cain, a mystery. London: William Crofts, 1830.

FRANCE, Anatole. Balzac, príncipe do mal. In: BALZAC, Honoré de. A Comédia Humana São Paulo: Globo, 1954. Vol. 6.

MANN, Thomas. A Montanha Mágica. Trad. Herbert Caro. Rio de Janeiro: Nova Fronteira, 2006

Doutor Fausto: a vida do compositor alemão Adrian Leverkühn narrada por um amigo. Trad. Herbert Caro. 4. ed. Rio de Janeiro: Nova Fronteira, 2000.

Tonio Kroeger/A Morte em Veneza. Trad. Maria Deling. São Paulo: Abril Cultural, 1971. Coleção: Os Imortais da Literatura Universal.

NUNES, Benedito. A visão romântica. In: GUINSBURG, J. (Org.). O romantismo. 3. ed. São Paulo: Perspectiva, 1993. p. 51-73.

PAZ, Octavio. A dupla chama: amor e erotismo. Trad. Wladyr Dupont. São Paulo: Siciliano, 1994.

. Os filhos do barro: do romantismo à vanguarda. Trad. Ari Roitman e Paulina Wacht. São Paulo: Cosac Naify, 2013.

RIMBAUD, Arthur. Uma Estadia no Inferno. In: de Janeiro: Topbooks, 1998. . Prosa poética. Trad. Ivo Barroso. Rio 
RIMBAUD, Arthur. Carta a Paul Demeny. In: . Correspondências. Trad. Ivo Barroso. Rio de Janeiro: Topbooks, 2009.

ROLLAND, Romain. Jean-Christophe 3. Trad. Vidal de Oliveira e Carlos Dante de Moraes. 5. ed. Porto Alegre; Rio de Janeiro: Globo, 1986.

RÓNAI, Paulo. A vida de Balzac. In: BALZAC, Honoré. A Comédia Humana: estudos de costumes: cenas da vida privada. Trad. Vidal de Oliveira. Rio de Janeiro: Globo, 1989.

Recebido em 17/02/2015

Aceito em $29 / 07 / 2015$ 